\title{
6 Kiss Me Quick: on the naming of commodities in Britain, 1650 to the First World War
}

\begin{abstract}
This chapter looks at some historical product-names, positing that regardless of origin, they were words like any other and subject to the same kinds of phonological, morphological and semantic changes that affected the rest of the lexicon. I focus on four linguistic processes which show merchants' innovations: the development of bound morphemes, conversion from one part of speech to another, semantic extension, and sociolinguistic innovation. My data comes from commodity-names retrieved from the British Newspapers 1600-1950 database, and two main areas of multilingual borrowing emerge: the names of commodities brought to Britain from abroad via trade, and names arriving in Britain as the result of defense policy when the Empire was threatened. A multilingual trading perspective reverses the traditional relegation of commodity-names to the sidelines of linguistic history, foregrounding instead everyday domestic conversations. This everyday lexicon directly reflected Britain's global political and economic partnerships with speakers of other languages.
\end{abstract}

\section{Introduction}

Textbooks on the history of the English language rarely devote much space to words which were the names of commercial products - too ephemeral, invented by traders and therefore somehow spurious, perhaps perceived as peripheral to the rest of the language which had evolved "naturally". Not proper English, in short. This chapter refuses to recognize this distinction, positing that for the speaker, product-names were words like any other, needing to be discussed (in pre-supermarket days) between customer and shop-assistant. A multilingual trading perspective reverses the traditional relegation of commodity-names to the sidelines of linguistic history, foregrounding instead everyday personal, domestic experiences such as reading newspaper advertisements, walking along urban streets, looking at labels on shop-goods and talking to shop assistants.

Laura Wright, University of Cambridge

DOI $10.1515 / 9781501503542-006$ 
This everyday lexicon directly reflected Britain's global political and economic partnerships with speakers of other languages.

Certain types of product advertised in British newspapers over the period 1650 to the First World War - including household items such as cloth, grocery, snuff, wine, card-games, tea - increasingly included foreign words in their advertising columns, many of which bore little relation to their phonological source. Since the British maritime trading empire began, British newspaper-readers were subject to innumerable borrowings. Commodity-names retrieved from the British Newspapers 1600-1950 database are found to have behaved like other parts of the lexicon, subject to reinterpretation and semantic development, and conversion from one part of speech to another. Words started life denoting one kind of commodity but then underwent semantic extension and became applied to others - depending on the decade, garibaldi was the name of a type of blouse (1860s), hat (1880s), fish (1880s), and also biscuit (1890s to the present). ${ }^{1}$ Two main areas of multilingual borrowing are considered here: the names of commodities brought to Britain from abroad via trade; and names arriving in Britain as the result of defense policy when the Empire was threatened (the latter was a particularly fruitful source of inspiration for traders). I focus on four linguistic processes which show merchants' innovations: the development of bound morphemes, conversion from one part of speech to another, semantic extension, and sociolinguistic innovation. I make no pretence at exhaustion; these four processes have been chosen in order to show both unconscious developments, such as happened when merchants fitted unfamiliar foreign names into their phonological systems; and conscious developments, as when names were invented $a b$ initio for commodities new to the market.

\section{Bound morphemes}

The British Empire is more or less coterminous with the British East India Company, which began trading in 1600. Wright (forthcoming) considers seventeenth and early eighteenth century cloth terms imported by the Company, many of which were the names of villages in Bengal where the cloth was produced.

1 OED Garibaldi, $n$. All commodity names discussed hereafter have been retrieved from the British Newspapers 1600-1950 database unless specified otherwise. I especially thank Alex Bergs for comments on an earlier draft. 
A word-final cloth-name element which repeats in British newspaper advertisements is -pore:

(1) Cargoe of the Colchester and the Fame from the Bay of Bengall, the Loyal Merchant from Bombay, and the Wentworth from China, arrived the 11th Inst. Viz.

Atlasses 2576, Atcheenbannees 1196, Alibannees, 704. Aubrowahs 1942, Baftaes 414,. Ditto broad, 13600, ditto narrow 6286, ditto broad blew 3140, ditto Baguzzees 480, ditto Ponabagguzzees 1980, Brawles 240, Chellanumfaree 120, Cabooter Coupee 109, Chints 44271, Chinachurrees 437, Cossaes 9146, Conches 168, Chowcarea 2400, Choradaries 3196, Chowtars 925, Chucklaes 1436, Cuddumpholeys 537, Cuttanees 1514, Damasks 3418, ditto Birds-eyes 727, Deribands large 1300, ditto small 2800, Dimities 856, Doreaes 7950, Dungarees 4000, Elatches 7422, Flower'd Cloth 336, Geelongs 160, Ginghams coloured 1239, Guinea Stuffs 21160, Gorgorons 402, Gungallary 298, Gurrahs 6594, Humhums 1603, Hummerlees 717, Jamwars 861, Jamdannees 588, Long Cloth brown 1790, Luckhowries 646, Lungees 1655, ditto Herba, 1903, Mamoodies 480, Mahumudhiattees 2670, Mulmuls 18476. Musters 296. Neckcloths 1321. Nillaes 1134. Niccannees large 1600. Ditto small. 6720. Pallampores 1158. Paunches 6103. Ditto coloured 2452. Pelongs Nankeen 2972. Ditto Canton 2818. Peniascoes 1277. Pegue 822. Photaes 1216. Phooleys 94. Poses 1730. Rehings 1139. Romalls 6574. Rungebangulpoor 380. Sallampores brown 2020. Sailcloth brown 440. Sannoes 2289. Sattins strip'd 523. Seersuckers 2142. Seerhudcanns 105. Seerbands 211. Silks flower'd 63. Sovaguzzees 10824. Soosannees 25. Sooseys 7399. Sorts Nunsaree, \&c. 565. Ditto Dungom 990. Taffaties plain 10130. Ditto Raw 556. Ditto Herba 1312. Ditto Chequer'd 196. Ditto strip'd 1977. Ditto Silver 344. Ditto Flower'd 230. Tanjeebs 12264. Tapsiels broad 800. Tannah Stuffs 144. Terrindams 756. Tunsooks 82 Pieces.

London Post with Intelligence Foreign and Domestick, August 11, 1701 August 13, 1701.

Pallampores (line 14) and rungebangulpoor, sallampores (line 17) fit into the pattern of other East India Company cloth-terms ending in -pore/poor, such as callawapores, monepore, bettellees gunapore, chints birampore. Most of these contain the Sanskrit place-name element pur- 'suburb, settlement': rungebangulpoor is rang 'muslin' from Bhagalpur, sallampores were a type of cloth from Salampur, monepore was cloth from Manipur, bettellees gunapore were muslins 
from Gunupur and chints birampore were chintzes from Birampur. ${ }^{2}$ However, the word-final element of pallampore and callawapore is likely to be derived from

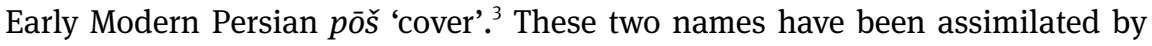
analogy to the -pore group, not by speakers of the original donor languages, but by speakers foreign to the place of manufacture along the trade-route to Britain. Similarly, seersuckers, seerhudcanns, seerbands (lines 18-19) show a word-initial cloth-name element seer-, fitting into a larger group of East India Company clothnames including seerbettees, seerhaudconnaes (possibly the same as seerhudcanns) seershauds, seerbafts, seerpaws. The predominant word-initial element is Persian sar, sir 'head', entering English through Urdu, prefixing the names of cloths that were used for turbans. However, seersucker contains Persian shìr o shakkar, 'milk and sugar', in reference to its stripes. Seersucker joined the seer- group by analogy, the meanings of 'head-cloth' and 'milk and sugar' being irrelevant to English-speaking merchants. Again, this development must have happened away from the place of manufacture, at a point where the original languages were no longer understood. ${ }^{4}$ Both -pore and seer-came to act as bound elements in English clothing vocabulary, but the very success of East India cloth in Britain caused an abrupt downfall. British cloth-manufacturers (including Huguenot weavers, the foreign traders of earlier generations) saw their livelihoods threatened, and petitioned parliament to grant them security. As a result, retailing East India cloth in Britain was outlawed, and by 1720 it was even illegal

2 See Wright (forthcoming) for discussion of these terms; "Rang is a muslin which resembles jhuna in its transparent gauze or net-like texture” Yule and Burnell (1886 sub Piece-Goods); OED Salempore, $n$. "of unascertained origin", "A blue cotton cloth formerly made at Nellore in India, and largely exported to the West Indies, where it was the usual slave cloth"; OED beteela, $n$. 'kind of muslin', etymology obscure; $O E D$ chintz, $n$., from Hindi chint 'variegated'. There are currently thirteen villages named Salampur in India, including two in West Bengal (http://villagesinindia.in/odisha/jagatsinghapur/tirtol/salampur.html); Bhagalpur was a cloth manufacturing centre in Bihar, Manipur is in eastern Bangladesh, Birampur is in western Bangladesh, and Gunupur is in Odisha.

3 OED palampore, $n$. "Hindi palang-poś 'bedspread, coverlet', from palang 'bed' from Sanskrit palyarika + early modern Persian pōš 'cover'. The palampore forms perhaps arose as an inferred singular of perceived plural palampores, palempores, which might have been attempts to represent the Hindi pronunciation (with long $o$ ) of the singular, with voicing of the final consonant after Portuguese. The medial - $m$ - is also likely to be after Portuguese pronunciation". See Wright (forthcoming) for a discussion of callawapores (callaway poos (1678), callaway poose (1688)), where I identify the second element as Persian pōš 'cover' as above, but the first element is unknown - possibly a settlement name, or possibly after two East India Company employees named Calloway.

4 See $O E D$ seersucker, $n$.; OED seerpaw, n.; OED baft, $n$.; Yule and Burnell (1886 sub PieceGoods) seerbands, seerbetties. Seerhaudconnaes/seerhudcanns/seershauds remain unidentified. Hindi ser 'weight measurement' may perhaps also be relevant (OED seer $n^{2}$ ). Word-final <-ee(s> is another spelling convention of East India cloth texts. 
to wear it. ${ }^{5}$ Cloth-terms such as the above, which had been established over a hundred years of trading, became largely abandoned.

Moving to another set of commodity-names that was very visible in press advertisements from around 1750-1850: the newspaper-reading public would have repeatedly seen the names of fireworks during the summer firing seasons. Fireworkers published the names of their fireworks week in, week out, year after year, in the "Order of Firing" timetables that publicized their attractions at the 200-odd pleasure-gardens in and around London. Expertise in fireworking at this time came from France, Switzerland and Italy, and French and Italian-speaking fireworkers dominated the London industry. The suffix -oon developed from the sixteenth to the eighteenth centuries in words borrowed from French with the suffix -on, especially where French had borrowed those words from Italian words with the suffix -one (OED -oon, suffix), and -oon became particularly productive in this semantic field. The prototype is likely to have been balloon, which is first attested in French in 1549 in the sense 'hollow spherical firework' (OED balloon $n$.):

(2) Twelve Water Rockets. 3. Twelve Water Genouillieres. 4. Six Water

Balloons. 5. Twelve Water Fountains

(from M. Caillot's Order of Firing at Ranelagh, Morning Chronicle, July 17, 1794)

(3) A GRAND FIRE-WORK, Under the Direction of M. CAILLOT. ORDER OF FIRING.

1. A Salute of Twenty-One Maroons

2. Two dozen Water Rockets

3. Twelve Half-pound Sky-Rockets

4. An Air-Balloon illuminated

5. A large Verticle Wheel in brilliant Fire of different Colours, which terminate with Aigrettes in Chinese Fire

(Advertisement for Ranelagh, The Times, June 2, 1791)

(4) 2 Jerbs. 3 Tourbaloons. 1 Fourloon. 3 Rockets

(Advertisement for Marylebone, Public Advertiser, July 16, 1770)

Maroons first appeared in the London press as marons (e.g. London Gazetteer, April 15, 1749), derived from French marron 'chestnut' and its etymon Italian marrone (OED maroon, n.1 and adj.1 A. n.1 2.a. "A firework designed to make a single loud report like the noise of a cannon (often with a bright flash of light)

5 See O’Brien, Griffiths and Hunt (1991: 398); Lee-Whitman (1982: 39). 
... the firework makes the noise of a chestnut bursting in the fire"). Although the French names of fireworks could have been translated - maroons could have been called 'chestnuts', genouillieres could have been 'knee-pieces', in reference to how they were fired, aigrettes could have been 'spangles', and jerbs could have been 'wheatsheaves' - the French and Italian names were kept in London advertisements, presumably to add foreign allure. A tourbillon (French for 'whirlwind') was a kind of firework which spun as it rose, and the second and third syllables, opaque in meaning to English fireworkers, were interpreted as containing the element balloon (OED tourbillion, || tourbillon 3.), although a tourbillon was not a balloon type of firework. The -oon suffix was also extended to fourloon, a kind of firework which has at least eighteen highly variant spellings in the London press (Wright 2011b: 130), probably ultimately from the Italian verb frullare 'to whirr'. ${ }^{6}$ This is a conflation of something that was productive elsewhere in English at the time (Italian - one and Spanish -ón > French > -on > English -oon), together with a perception that the -oon morpheme was suitable for that semantic field, just as -pore and seer- had become perceived as fitting components of the East India cloth-naming word-stock. ${ }^{7}$ The process would have occurred within the speech of industry-insiders, the merchants who dealt in cloth and the fireworkers who made and sold fireworks, rather than that of the general public.

Similarly, the process known as Hobson-Jobsonizing (turning a foreign phonological string into whatever word/s it approximates in English, however meaningless the result) is something that would have happened in the speech of English fireworking apprentices, on hearing technical terms from their French and Italian masters. The French firework known originally as an aigrette 'spangle' became anglicized as air greets:

6 wheels of frueli, friulonies, friuloni, furiloni wheel, fruilioni, fruiloni wheels, furilloni wheels, flurious wheels, flurioni wheels, flurione wheels, thurioni wheels, fourloon, furilonii wheels, fourlony wheels, furlony wheels, fourloney wheels, forlony, frailona wheel; provenances in Wright (2011b: 129-30).

7 The spelling of the suffix in maroon, air balloon, water balloon, tourbaloon/tour balloon, fourloon had settled down to (predominantly) <-oon> by the second half of the eighteenth century, from variants <-on, -one, -oun(e, -own(e>. It is complicated by multiple input: some words in -oon are borrowings into French from Spanish and Italian augmentatives (balloon, poltroon, cartoon, festoon); some seem to come direct from Spanish (picaroon); some are native French (harpoon), some are French borrowings (dragoon, shalloon); and some were formed in English (spittoon). To cloud matters further there were two opposing semantic thrusts: the Spanish and Italian augmentative (mantoon 'large cloak', doubloon 'coin double the value of a pistole') versus the French diminutive -on (mandilion 'type of coat', marmiton 'type of minion', minion). Pronunciation is unclear: $O E D$-oon, suffix: "French -on / $\tilde{J} /$ seems to have been identified by Englishspeakers with the close rounded back vowel /u:/ in the early modern period (and as late as the early 18th cent. ...); but the considerable variation in spelling of the element between -oon, -on, -one, and even -oun suggests that other pronunciations also occurred". 
(5) Two Balloon Wheels illumined and decorated with Pots d'air Greets. (Advertisement for Ranelagh, Public Ledger, June 30, 1766)

I have counted twenty-four spelling variants between 1747 and 1798 in London advertisements for this particular firework, showing the process of oral transmission from French-speaking master to English-speaking assistant, whether fireworker or printer. ${ }^{8}$ The general public could not have been expected to decode the original meaning of callowapore, thurioni wheel or pow de grate, or even to have reliably related them to other visual manifestations of the same commodity, such as calloway poes, frailona wheel or pots daignettes. This kind of variation is the result of oral transmission without translation, where someone along the trading chain did not understand the term in the original language. Meaning, however, was less important when it came to point of sale than other, more valuable, social, information conveyed by foreign-looking words. The overall meaning (a type of cloth, a type of firework) could not be mistaken in the context of a press advertisement, and the names' very impenetrability conferred an exotic appeal. How new, how modern, how very à la mode, to go dressed in atcheenbannee to view the latest flurious wheels in London in 1701. The selling-point was a sense of up-to-dateness and exclusivity - which novelty and exclusivity would have been reduced had the customer been able to translate.

\section{Conversion}

I move now to personal names, and the nineteenth century. The nineteenth century was a time of much innovation in the field of applied chemistry, resulting in new substances marketed as drugs, dyes, perfumes and disinfectants. A common naming procedure for new products was to add suffixes to the name of the inventor in order to give nouns, verbs, modifiers and verbal nouns. For example, the words kyanised/kyanising and burnettised/burnettising, 'wood that has been/is being treated with patented preservative', invented by John Howard Kyan and Sir William Burnett respectively, were in use from the 1830s to the 1860s:

(6) In the Great Western it is proposed to use kyanised timber only.

The Standard, August 20, 1837

8 pot a aigrette, pots d'airgrets, pots d'aigrettes, pots de airgrets, pots d'airgretts, pots degritts, pots de airgreet, pot de airs grets, pots des aigrettes, pots d'air greets, po's dair greets, pots d'aigrets, pots d'agrettes, pot d'egret, pots de'airgrets, pots de air-grets, pot d'agret, pots daignettes, pots dargrettes, pow de grate, pots d'aigrete, pots de grats, pots de grete, pots d'aigrette; provenances in Wright (2011b: 127). 
(7) The Admiralty have given directions that the Burnetising process is to be brought into full operation.

The Standard, June 8, 1848

Kyanising, and burnettising which replaced it, were superseded by changes in technology (treating wood with creosote) so the products and the words fell out of use in the 1860s, but during their thirty-year lifetime they were high-frequency items much in the news. Faraday spoke upon kyanising in his inaugural lecture at the Royal Institution, and Birkbeck lectured on kyanising at the Society of Arts. An Act of Parliament was passed for the building of great kyanising tanks at Grosvenor Basin, at the docks at Rotherhithe, and at the City Road canal basin. The palings round the Inner Circle of Regent's Park were kyanised, and small brass plates were attached at intervals announcing the fact. The Gentleman's Magazine in 1841 reported that kyanising had practically become a craze, to the extent that a man had had his coffin kyanised. Like other crazes, it was satirized by Charles Dickens. In his Kyan's Patent - the Nine Muses, - and the Dry-Rot, the Nine Muses on Mount Parnassus discuss anti-dry-rot treatment (and sing a song with rather nice rhymes in the burden which go a shy 'un, a shy 'un / a dry 'un, a dry 'un! / a-nigh 'un, a-nigh 'un / with Kyan, with Kyan!). ${ }^{9}$ Kyanised, kyanising do not equate to present-day proprietary names for wood-treatment products; rather, they would have been a contender for the Victorian British equivalent of the Linguistic Society of America's Word of the Year. ${ }^{10}$

Kyan+suffixes was actually not Kyan's own coinage. His preferred term for his wood-preservative was corrosive sublimate, but it did not take with the general public, who preferred a simple conversion of his name. I move now to an inventor's name + suffix which almost certainly was deliberately chosen by the inventor himself, pulhamite, marketed as a type of artificial stone and invented some time in the mid-1800s by James Pulham of Broxbourne, Tottenham and Spitalfields. Pulham took advantage of the craze for having one's own fernery, which started in the 1840s and reached a heyday in the 1870s (shrubberies had been in vogue for the preceeding hundred years; rockeries, crazy-paving and gnomes were yet to come). Fern-collectors were known as pteridophilists, 'lovers of ferns', and mid-century pteridophilists would buy different types of ferns and try to grow them. However British domestic back gardens tended to be lawned and flat, whereas ferns grow in damp crevices in rocks.

9 'Boz' (1837: 93-98). The Nine Muses sing whilst enjoying a celebratory dinner at the Macclesfield Arms in the New (now the Euston) Road, having triumphed over dry rot.

10 For references and further illustration, including the use of kyanised metaphorically in literature, see Wright (2013). 
What was really needed was a cliff, or a ravine, preferably with a waterfall. But urban pteridophilists were not to be daunted (many of them being doughty Victorian ladies) and, with the kind of determination that ruled the British Empire, they went out and ordered themselves scenery. Importing a ravine into one's backyard was no small undertaking, so James Pulham invented a process of covering builders' rubble with coloured cement which he and his firm artistically textured and shaped to resemble natural rock. As with kyanising, during its lifetime, the word pulhamite was ubiquitous: James Pulham and Son built pulhamite ferneries in suburban gardens in Beckenham, Brixton, Clapham, Croydon, Dulwich, Forest Hill, Upper Norwood, Lower Clapton, Ruislip, Isleworth, Hayes, Hendon, Norbiton, Tottenham, Peckham, Streatham, Sydenham, West Wickham and Winchmore Hill. ${ }^{11}$ There may have been more, possibly still extant in back gardens. The Queen has a pulhamite fernery in hers at Buckingham Palace, and pulhamite can be viewed in the lake at St James' Park, where Pelican's Island was built of pulhamite between 1895 and 1899, at the "gothic ruins" in Gunnersbury Park, built for Baron de Rothschild in 1876, and at the Boating Lake at Battersea Park, with its nearby "crags" and "caves”, the grandest being known as the Victorian Cascade and over which water used to flow, built by James Pulham and Son in the late 1860s. Not a few Victorian seaside councils ordered pulhamite features for their gardens and promenades too, such as Albion Place Gardens, Victoria Parade Gardens, Royal Parade and Madeira Walk, all in Ramsgate, and Cliff Garden, Felixstowe. Some seaside councils went further, placing pulhamite rocks on the actual seafront itself, to make it look more rocky - Blackpool seafront was thus decorated in the 1910s. At Lower Leas, Folkstone, a whole series of zigzag paths and tunnels was built from pulhamite at the same date, in order to get holiday-makers down the cliffs in properly scenic fashion. Pulhamite was used at Winterstoke Undercliff, Ramsgate, to help visitors transition to the beach via something more interesting than steps against a flat sea-wall (Folkstone and Ramsgate in particular splashed the town budget on pulhamite). The -ite suffix was one of many available in English for forming nouns, becoming productive in the nineteenth century attached to names. ${ }^{12}$ It was especially used for the names of newly-discovered minerals, usually attached to the name of the discoverer, or an honorand: wernerite (1811), humboldtite (1823), brewsterite (1843), darwinite (1860),

11 This information is taken from the work of master pulhamite detective Claude Hitching, Hitching (2012) and at http://www.londongardenstrust.org/features/Pulham2012.htm; http:// pulham.org.uk/where/london/. See also http://en.wikipedia.org/wiki/Pulhamite.

12 See $O E D$-ite, suffix1 2. b. Min. 
whitneyite (1861). ${ }^{13}$ Pulhamite, of course, was not a newly-discovered mineral but it sounded like one, and enjoyed the cachet.

\section{Semantic extension and exploitation of borrowing}

I now return to borrowings, to which traders gave new life beyond their original meanings. Beginning with banyan, a London tailor's bill of 1737 reads:

(8) Nov $y^{e} 9$ For takeing $y^{e}$ spots out of young Masters Searles Banyon £0 0s 9d for 2 doz \& 4 brest buttons at $8^{\mathrm{d}} \mathrm{p}($ er $) \mathrm{doz}$

$£ 01 \mathrm{~s} 7 \mathrm{~d}$

for a Velvet coller lining

$€ 0$ 1s Od

for silk \& silk twist for the holes

$€ 01 \mathrm{~s} 4 \mathrm{~d}$

for Buckram \& Canvas stayes

£0 0s 9d

for work done to the Banyon

$€ 02 \mathrm{~s} 6 \mathrm{~d}$

C. Hoare \& Co. archive, Richard Hoare's bill, 1737

Banyan was a common eighteenth-century English borrowing meaning a loose gown, from "Portuguese banian, probably from Arabic banyān (16th cent.), from Gujarati vāniyo man of the trading caste, ultimately from Sanskrit vaṇij merchant", first attestation in English a1597, first attestation in the clothing sense 1725 (OED banian, n.) OED banian, $n$. C2. banian-tree n.: "1638 T. Herbert Some Yeares Trav. (rev. ed.) 122 A Tree (or rather twenty Trees, the boughs rooting and springing up a whole aker together)..namd by us the Bannyan Tree, from their adorning and adoring it with ribbons and streamers of varicoloured Taffata”. A banian meant a trader or a broker in the Indian languages, but Europeans saw banians sitting under specific trees out of whose boughs they had formed a pagoda, wearing specific clothing, and transferred the name to both tree and clothing. Banian only signified a type of gown or tree in European languages, not Indian ones. The sense-developments are, however, linked to the source; in context, a banian(-type gown) or banian(-type tree) did not need to be fully expanded. This is unlike the uses to which traders put the names of contemporary battles, where there really was no link, semantic or otherwise. In Wright

13 OED wernerite, $n$., humboldtite, $n$., brewsterite, $n$., darwinite, $n .2$, whitneyite, $n$. Pulhamite has no $O E D$ entry. After the fernery craze died down, the term pulhamite lived on, as the company of James Pulham and Son reapplied the name to a stone-coloured terracotta used for ornamental garden furniture. From the late nineteenth century pulhamite also referred to a less theatrical garden product - sundials, balustrades, birdbaths, urns, and so on. 
(2011a; see references therein) I discuss the pink-mauve colour-term magenta. Early names for this newly-developed aniline dye were roseine (1859), rubine (1862), fuchsine (1865), aniline red (1865), rosaniline (1872), usually named by the inventor. The successful name, magenta (1860), was the name of the town in Northern Italy after which a battle was named in 1859, where the Austrians were defeated by the French and Sardinians in the Franco-Piedmontese War or Second War of Italian Independence. The colour, it has been claimed, is semantically linked to the battle, e. g. Collins English Dictionary: "named after Magenta, Italy, alluding to the blood shed in a battle there". However, this cannot be the case on two counts. The colour-term magenta (despite its synonyms rubine, aniline red) has always designated a pink-mauve colour unlike that of blood. In order to ascertain this I tracked artists' colour-tint cards from the second half of the nineteenth century, and although the dye itself might have changed colour over the intervening 130-odd years, the labels have not. Magenta was classified with the violets and mauves, not the reds:

(9) Magenta. Cobalt violet. Mineral violet. Mauve. Permanent violet. Permanent mauve. Mineral violet, 2. Mauve, 2.

Specimen Tints of Winsor \& Newton's Artists' Oil and Water Colours, p.1878-a.1882.

This is Winsor and Newton's earliest tint card showing the magenta strip. ${ }^{14}$ Secondly, there was another similarly-coloured dye, the name of which did not catch on, named solferino. Oberthur and Dautheny et al (1905) is a dictionary of European colour terminology, as by 1905 the numerous patented dye-names in the various European countries had proliferated and overlapped to such an extent that tables of comparisons were needed. Oberthur and Dautheny et al (1905: $182,169)$ list under the headword "Magenta rougeåtre Origine: Combinaison du Magenta et du Solférino" the French synonyms "Solférino de Lorilleux (impropre). Solférino violacé". Solferino, attested as an aniline dye-name in English in $1861,{ }^{15}$ was also the name of a Northern Italian town near which a battle was fought in the Franco-Piedmontese War of 1859. These newly-synthesised dyes were named after towns which were repeatedly in the newspapers from June 1859 onwards for the next couple of years. In trade, novelty was key, and battles and their participants' names lent an immediacy, a dernier cri modernity, regardless of whether there was any link at all with the goods. Names such as Trafalgar,

14 There are copies at Winsor and Newton's Wealdstone factory, the National Art Library and the British Library.

15 Scientific American 4: 150, antedating OED solferino, n. c1865. 
Waterloo, Wellington, Raglan, Cardigan, Sandwich and so on were applied to furniture, dyes, food, confectionary, clothing and all sorts of other commodities. Battle-names in particular were taken up in Britain by speculative builders:

Table 1: British addresses named after theatres of war, retrieved from http://www.royalmail.com/

\begin{tabular}{|c|c|c|}
\hline UK street name & $\begin{array}{l}\text { No. of UK } \\
\text { addresses }\end{array}$ & $\begin{array}{l}\text { Battle location and } \\
\text { date }\end{array}$ \\
\hline Waterloo & 3702 & Belgium, 1815 \\
\hline Alma & 3657 & Crimea, 1854 \\
\hline Kimberley & 3519 & S. Africa, 1899 \\
\hline Trafalgar & 2365 & Portugal, 1805 \\
\hline Mandalay & 1191 & Burma, 1887 \\
\hline Portobello & 525 & Panama, 1739 \\
\hline Ladysmith & 521 & Natal, 1899 \\
\hline Inkerman & 338 & Crimea, 1854 \\
\hline Odessa & 291 & Crimea, 1853-6 \\
\hline Mafeking & 266 & S. Africa, 1899 \\
\hline Lucknow & 221 & India, 1857 \\
\hline Magdala & 180 & Ethiopia, 1868 \\
\hline Balaclava & 161 & Crimea, 1854 \\
\hline Crimea & 90 & Crimea, 1853-56 \\
\hline Plevna & 85 & Bulgaria, 1877 \\
\hline Kandahar & 78 & Afghanistan, 1879 \\
\hline Khartoum & 75 & Sudan, 1885 \\
\hline Sebastopol & 56 & Crimea, 1854-55 \\
\hline Varna & 54 & Bulgaria, 1877 \\
\hline Abyssinia & 33 & Ethiopia, 1868 \\
\hline Omdurman & 14 & Sudan, 1896 \\
\hline Spion Cop & 7 & Natal, 1900 \\
\hline Shipka & 7 & Bulgaria, 1877 \\
\hline Meerut & 5 & India, 1857 \\
\hline Ulundi & 5 & Zululand, 1879 \\
\hline Taku & 4 & China, 1859 \\
\hline
\end{tabular}

Practically all of these were residential streets, named by the speculators who built the houses and named to underscore the impeccable newness of the property rather than invoke the country or battle in question, although patriotism did have an appeal for some prospective buyers - the 1856 census lists children named, e. g., Wellington Charles Inkerman, Walter Alma Peace Inkerman, Alma Odessa, Rebecca Sebastopol, Canrobert Raglan. ${ }^{16}$

16 General Canrobert led the French and Lord Raglan led the English at the Battle of Inkerman. 


\section{Exploitation of sociolinguistic information}

The final traders' linguistic technique considered here is that of sociolinguistic exploitation, for which I turn to the selling of perfume. Scented water is now considered to be a non-essential, luxury commodity, but prior to the First World War it was regarded as rather more functional, having the property to ward off airborne germs and included as "toilet vinegar" in first-aid kits. Before 1710, London perfumers puffed eye-water, hair-water, gout remedies, tooth-ache remedies, dentifrice, kidney stone remedies, balsam for preventing apoplexy, sudden death, \&c., scorbutick water, oils and elixirs, cordial drops, spirits and treacles against arthritis, liquid to cure the bite of a mad dog, essence against colds and coughs, hysterics and convulsions - but not perfume. Perfume was not advertised to any extent until the 1810s, and when it began, the predominant language was English. It was only in the 1820s that French perfumiers started to become successful in London - and, conversely, English perfumes became fashionable in Paris. I have noted the following multilingual names in British newspaper advertisements up to 1857:

(10) Aqua Mellis; or, the King's Honey-Water (Charles Lillie, 1721); Konigsrauch, or Royal Perfume (S. James \& Co., 1821); Atkinson's Persian Bouquet de Rose, Genuine Eau de Cologne, from Farina of Cologne, and Chardin Hubigant, of Paris (1828); Esprit de Lavende aux Mille-Fleurs; Perfume Bouquet du Roi G. I.V.; Eau de Camelia et Vitiver (Delcroix, 1828); Concentrated Essence of Otto of Roses aux millefleures (Atkinson, 1829); Jean Devereaux's Esprit de Lavande au Portugal, Eau de Camelia, Esprit Bouquet du Militaire, Esprit de Rose, Muguet, Marchalle, Rezeda, Chevrefeuille, Portugal, Mousseline, Bouquet des Dames, \&c. (Devereaux, 1830); Esprit des Fleurs de la Violette Napolitaine (Hendrie, 1834); Bouquet de Haut Ton (Dickens, 1835); Extrait de Magnolia (Atkinson, 1837); Blount's Royal Eau de Bouquet (1837); La Bouquet d'Isabelle (Drew, Hayward \& Co., 1838); Parfum D’Arabie (S. Poole, 1839); Bouquet de la Famille Royale d'Angleterre (Delcroix, 1839); Bouquet du Prince Albert de Saxe Coburg (Delcroix, 1840); Esprit de Violette, Melarosa Florenti (Hendrie, 1842); Bouquets De la Reine Victoria, du Prince Albert, du Prince of Wales, de la Princesse Royale (Delcroix, 1843); Bouquet d'Arabie (Best Ede, 1843); La Reine des Alpes (Ross \& Sons, 1847); Rimmel's Bouquet de Jenny Lind (1847); Viner's Blumenhauch. - The Breath of Flowers (1848); Val d'Andorre Bouquet (L. T. Piver \& Co., 1850); Breidenbach's Extraits D’Odeurs (1853); Bouquet de la Reine Victoria (Rigge, Brockbank, Rigge, 1854); Eau de Berlin (Hoffman \& Co. 1855); La Duchesse Perfume (Phillipson \& Co., 1857) 
One perfume-title is Latin, two are German, one Italian, and the rest French, starting with Atkinson's importation of Farina's Eau de Cologne. The oldest sociolinguistic technique was to invoke socially elevated personages, starting with royalty: The Princely Perfume (Daily Courant, June 30, 1708); the King's Honey Water (Post Boy, August 26, 1721 - August 29, 1721).

\section{Made, and Sold Wholefale and Retail,}

B Y

\section{Cbarles 造itrié, Perfumer,} At the City of Barcelona, the Corner of BeaufortBuildings in the Strand, Londont.

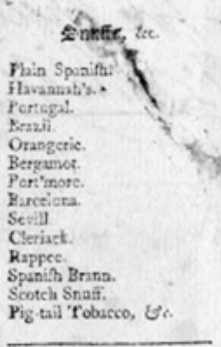

efrnces, 3 Butters, ano
פpis.

Efence of Jefiamy.

Bfence of Orange-Sowen.

Eicnce of Ambergrezile

Esence of Mosk.

Bience of Bergamot.

Efence of lecmons:

Oil of feltany.

Oil of felianay,

Oil of Javends.

Oil of Iavetad.

Oil of Behn.

Orange-fower Bottes

I.cmon Batrer.

Cold Creams.

Ponatems for the Face as

Hais, Eै.

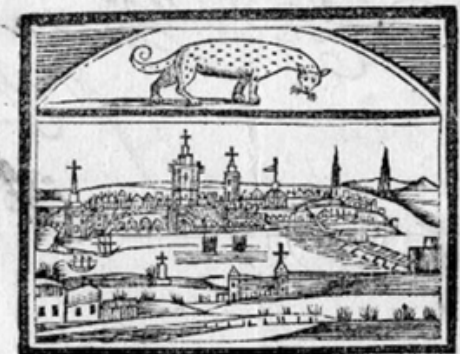

Woraun'o cuaters.

Agat Mollis, or, Fte King's

Hincy. Water.
Orange Alower Water.

Orange Alower Water.
lavender Wates.

Lortagal Watcr.

Portagal Watcr.

Amber Watcr.

Ulengary Wator from Mus.

pellor, ses.

Soaps ano zalibballø.

Amser WaAballs.

Bolegas Wafballs.

Cimpbir'd Warballt.

Jerabien WaAblls.

Chymiral Wafabuls
Niples Scap.

Jopps Sosp.

Geaca Soap.

Veaice Soap.

-lilarl Suas, acs.

IPait s polotere, \&c.

Oraxge-fower Powder.

Asuber Perfumid Powder.

Mask Ponder.

Visolet Pomiler.

Rale Powler.

Dasnakk Powder.

Jeflamy Powder.

Orice Powder.
Brown and Bluck Porveks

Fine Ptin Powder.

Cyjocls and Damak Pown.

dern, Giturs for Sivect Bags.

Lisinen, Truak, $\mathcal{O}_{0}$.

Werfumes, Cotmeticls, arcmaticke, kcc.

Antergreafe.

Matk and Civct.

Putvit.

Bulfam Apopictive

Pearl Powder from india.

Bifmurh.

Franch Red

French R

A liguil white for the Face. S liguil White for the

Pcrtugal Difbet.

Spanith Wool.

Ail Colous ; from China

Beari Greafe.

Alians 1 Pele.

Powder Rags and Boxce.

Powder PuIl of all forts. Lip Salve.

Teeth Porder.

Polund Starch.

Common Sert.

Indico and Porsder Blaces.

Stufor Pocict Botiles.

Sponges.

Perfanes to burn.

Powler Machince.

Bores for Wathilit.

Cafss for Oil Bottles, Eso

Plate 1: Charles Lillie's trade-card, 1736. The medieval perfumers' sign at the top of the cartouche is the sign of the civet cat, the scene underneath depicts the then-current name of the building, the City of Barcelona. Note: no French. On the dorse is a bill: "June 161736 $\operatorname{Rec}($ eive)d for 6 pounds of Sup(er)fine Rice'd Powder six shill(ing)s p(ar) Ch: Lillie”. British Museum number 1910,1208.14, AN1123604 
The first non-generic mentions of royalty were Perfume Bouquet du Roi G. I.V. (Delcroix, 1828); His Majesty's Perfume, Bouquet du Roi G. IV. (Jean Devereaux, 1829); Her Majesty Queen Adelaide's Refreshing Perfume (Price \& Gosnell, 1830); Royal Adelaide Perfume (W. Brewster, 1832); The Royal Adelaide Perfume (Robert Low \& Son, 1833); Adelaide Bouquet, King William Perfume, Victoria Bouquet (Rigge, Brockbank and Rigge, 1834). In particular there was a flurry of codeswitching into French around Queen Victoria's ascension to the throne and her marriage to Prince Albert in 1840: Bouquet du Prince Albert de Saxe Coburg, prepared expressly in honour of the approaching happy event (Widow J. Delcroix \& Son, 1840). Like Albert, Adelaide was also German and lived in Germany until her marriage to William; the British royal family was the House of Hanover, and there were German perfumers in London, one of the main innovators of perfume titles being Breidenbach, although he mostly advertised in English and French. Delcroix and Devereaux, two French perfumers (and their families) who lived and worked in London were highly influential in introducing French, rather than German, as the predominant other language in this semantic field. Eau de Cologne was the most popular perfume, sold everywhere and ousting the previously-popular Hungary Water - but it was sold in London via the French language, not the German of Cologne, nor the Italian of Giovanni Maria Farina, its inventor. By the 1840s perfumers were running short on British royals: Royal Bouquets: viz:- De la Reine Victoria, du Prince Albert, du Prince of Wales, the Queen Dowager's, de la Princesse Royale (Widow J. Delcroix \& Son, 1843) and got started on foreigners: The Emperor of China's Perfume (Robert Best Ede, 1846); The Napoleon Perfume (Emily Dean, 1850); The Empress Eugenie's Nosegay (Breidenbach, 1853); Eau de la Reine de Hongrie (Piesse \& Lubin, 1856). Perfumes were not yet restricted to the female market, neither were they worn on the skin: Scents for the Waistcoat-pocket and Reticule: Rose, Violet, Musk, Tonquin, Mareschal; Essences, \&c., in Verbena, Geranium, Forget-me-not, Patchouli (Viner, 1846). In the 1850s an upper-class lifestyle began to be invoked:

(11) Guards' Club Bouquet (L. T. Piver \& Co., 1850); Jockey Club Bouquet (Rigge, Brockbank, Rigge, 1854); Yacht Club Nosegay, and the Royal Hunt Bouquet (Breidenbach, 1854); The Oxford and Cambridge Bouquets (Metcalfe, Bingley \& Co, 1857); The Belgravia. - a new and aristocratic Perfume (L. T. Piver, 1857).

But aspirant-lifestyle titles aping the pursuits of the upper classes were quickly superseded by hot-news, latest-craze titles: 
(12) La Reine des Alpes, a beautiful new perfume (Ross and Sons, 1847); The Chobham Camp Nosegay. - A new and exquisite perfume of rich and delicate fragrance, from very rare flowers (Breidenbach, 1853); Medjid, or Royal Turkish Perfume (Rigge, Brockbank, and Rigge, 1854); New Crystal Palace Bouquet (James Lewis, 1854); Little Dorrit's Nosegay (Piesse \& Lubin, 1855); Honour to the Brave. - The Victor's Bouquet, and entirely New Perfume with emblematic device representing the glory and success of our heroes in India (G. T. Jerram, 1857); Postage Perfume (Piesse \& Lubin, 1871), Suez Canal, stilled from the Sacred Lotus Flower of Egypt (Piesse \& Lubin, 1875); Pyramid Perfume (October 25, 1882).

La Reine des Alpes of 1847 is a very early trend allusion as it was not until 1852, when Mr. Albert Smith's Ascent of Mont Blanc opened at the Egyptian Hall, Piccadilly, on a stage resembling a Swiss chalet, that British tourists realised they actually wanted to go to the Alps. The Chobham Camp Nosegay, advertised in July 1853, refers to the camp of eight thousand soldiers mustered at Chobham in Surrey between June and August in training for the Crimean War. Large crowds, including royalty, went to watch them practice. Medjid is in reference to the Sultan of the Ottoman Empire, Abdulmecid, who was fighting alongside Britain in the Crimean War against Russia on May 31, 1854, when the perfume was first advertised. Five days earlier the Times had reported "By order of the Minister of War, the English airs, God save the Queen and Rule Britannia, and the march of The Grand Sultan Abdul Medjid Khan" (which had been hastily composed for the event) "shall in future form part of the repertory of all the bands of the army" ${ }^{17}$ The New Crystal Palace Bouquet, advertised June 29, 1854, was in reference to the Crystal Palace which had housed the Great Exhibition of 1851 in Hyde Park and which had been removed to Penge Common, reopening in June 1854. Little Dorrit was first anticipated in the press in early November $1855,{ }^{18}$ the first instalment was out by December 2, and Piesse \& Lubin advertised Little Dorrit's Nosegay on December $16 .{ }^{19}$ Honour to the Brave, advertised on December 16, 1857, is in reference to the Second Battle of Cawnpore in India's First War of Independence of 1857, which led to the dissolution of the East India Company in 1857-8 and the foundation of the British Raj. Pyramid Perfume, advertised on October 25, 1882

17 The Times, May 27, 1854: 10.

18 The Lady's Newspaper, November 3, 1855.

19 Bell's Life in London and Sporting Chronicle, December 16, 1855. 
was probably in reference to a drawing in The Graphic of October 21, 1882, of the Duke of Connaught ascending the Pyramid of Cheops, whilst in the vicinity fighting the Anglo-Egyptian War.

Sociolinguists usually focus on social groupings - communities of practice that are interactive, whereas merchants and traders target customers (e.g. collectors of toy soldiers, people who want to go on a cruise) who do not form a necessarily interactive group. ${ }^{20}$ Dissemination of vocabulary may be one-sided: a reader could have been persuaded to buy a ticket to see fireworks by dint of repetitive advertising, without ever actually uttering the words fourloon, tourbaloon, or indeed even ever hearing them spoken aloud. The fireworking terminology presented in the advertisements nevertheless formed part of the newspaper-readerships' passive language repertoire. Traders target customer-bases that cut across the traditional social groupings of gender, class or age, revealing more specific social commonalities. The Bank Holidays Act of 1871 served to institutionalise an older set of social behaviours whereby lower-middle and upper-working class women could approach men - even those unknown to them - on certain designated days of the year (Easter Monday, Whit Monday, August Bank Holiday Monday, Boxing Day). Far from wanting to emulate an upper-class lifestyle, ladies of the upper and upper-middle classes could only listen enviously to accounts of Bank Holiday freedoms enjoyed by women further down the social scale. The Bond Street firm of Piesse and Lubin capitalized on this phenomenon, and aided, if not actually caused, the shift away from perfume worn on the handkerchief by both sexes to repel unpleasant odours and germs, to perfume worn on the skin by women to enhance allure:

(13) Kiss Me Quick (1858), Stolen Kisses (1858), Box His Ears (1860), Tom-Boy, Pop-Kiss, Follow Me, Lads!, Kiss Me, and Let Me go; Kiss Me, You Dare! (1876), Jolly Dogs (1876).

The song Kiss Me Quick and Go, words by Silas Sexton Steel, music by Frederick Buckley, had appeared two years earlier in 1856 in the sheet-music Boosey's Christy's Minstrels Album containing their Twelve Most Popular Songs. However the phrase kiss me quick had been in use before: kiss me quick was the name of

20 A definition of "community of practice" is "groups of people who share a concern or a passion for something they do and learn how to do it better as they interact regularly" (Lave and Wenger 1991). 
a small bonnet standing far back on the head in the early $1840 \mathrm{~s}^{21}$ and Kiss me Quick had been the name of several racehorses. ${ }^{22}$ The perfume Kiss Me Quick seems to have been particularly successful as other perfumers also used the title. ${ }^{23}$ The Google Ngram Viewer shows a discrete usage of the phrase "kiss me quick" between 1818-1831, and another usage from 1846 to the present, with a huge peak between 1865-1875, its heyday as a catch-phrase. Frederick Buckley also had a song entitled Stolen Kisses, published in 1859 but possibly performed in the music halls a few months previously. ${ }^{24}$ The phrase stolen kisses had been apparent in the press in 1855 as a quip from the New York Ladies' Repository and was syndicated in regional British newspapers in June, 1855: "Stolen kisses are said to have more nutmeg and cream than other sorts ... A stolen kiss is the most agreeable.” This quotation continued to circulate in British newspapers for over two years. ${ }^{25}$ Jolly Dogs was another popular song, current from 1865 . It was written by Harry Copeland and sung by The Great Vance, amongst others. The Jolly Dogs in question are young men who drink wine and go out a-larking, with the chorus:

They always seem so jolly oh, so jolly oh, so jolly oh

They always seem so jolly oh, wherever they may be

They dance, they sing, they laugh ha ha

They laugh ha ha, they dance, they sing, what jolly dogs are we

Fal la la, Fal la la, Fal la la,

Fal la la, Fal la la, Fal la la

21 OED kiss-me-quick, $n$. 1., first attestation: 1852 "G. W. Bungay Crayon Sk. (1854) 372: She wears..a Kossuth hat instead of a 'kiss-me-quick"; however, this is antedated by the Liverpool Mercury April 7, 1843: “A Popular fashion. - 'Kiss me quick!' is the name of a new fashioned bonnet worn by the ladies somewhere, and invented by somebody. The gentlemen find them very convenient, and the ladies exceedingly pleasant. The demand for them is becoming very great. New York Union." The same date, April 7, 1843, the Vermont Phoenix published: "A Laughable Scene. - On Saturday morning several young ladies made their appearance in our markets with 'Kiss me-quick mother's coming' bonnets on their heads, and some of the butchers indulged in a little sport at the expense of these votaries of the top of the fashion. "Kiss me quick! Kiss me quick!" escaped the lips of the butchers, and as it fell upon the ears of the young ladies, a blush of deep crimson mantled their cheeks. ... - Philadelphia Sentinel."

22 E. g. The Times May 25, 1846.

23 E. g. “Felix Sultana's Golden Casolette, which unceasingly emits a delightful fragrance, 1s.; the Fairy Fountain, six different perfumes in box, 1s.; Queen Dagmar's Cross, a jewel for a lady's neck, deliciously perfumed, 5s. 6d.; a bottle of Jockey Club, Wood Violet, and Kiss Me Quick, in case, 4s. 6d.; genuine otto of roses, in original bottles, 3s. 6d. All post free. Felix Sultana, Royal perfumer, 23, Poultry, city; and 210, Regent-street, London.” (The Times, March 6, 1865).

$24 \mathrm{http} / / /$ otbrass.com/PublishedMusic/Notes/D_Page.html.

25 E. g. Liverpool Mercury, June 26, 1855; Trewman's Exeter Flying Post, August 6, 1857. 
Fal de the ral, de the ral lal li do

Slap, bang, here we are again

Here we are again, here we are again

Slap bang, here we are again, what jolly dogs are $w^{26}$

In 1861 Piesse and Lubin advertised their Fountain Finger Ring, with which ladies could squirt prospective gentlemen at balls. ${ }^{27}$ The Fountain Finger-Ring was part of a wider practice of squirting people with odiferous liquid. In London, Easter Monday, Whit Monday and the August Bank Holiday had become associated with outings to fairgrounds on heaths and commons, and certain Bank Holiday customs arose, for evidence of which I turn to journalism:

(14) Up the road, in a word, come boys and girls, men and women, old and young, in rags and in finery, married and single, with babies and without; and all the way by the roadside vendors of "ladies' tormentors", long feathers known as "ticklers", penny bagpipes and tin trumpets, stand contributing to the general uproar. (Adcock 1903: 116). ${ }^{28}$

The definition of ladies' tormentor is found under $O E D$ tormentor $n$. 3. f. "A device used to annoy at pleasure-fairs (freq. a device for squirting liquid)", first attestation f.1891, last attestation 1912. The liquid in question did not smell pleasant. Ladies' tormentors are found in fiction of the period:

26 Written and composed 1865 by Harry Copeland, performed by Frank Hall, Alfred Vance and Tom MacLagan (http://monologues.co.uk/musichall/Songs-S/Slap-Bang-Here-We-Are-Again. $\mathrm{htm})$.

27 "FOUNTAIN RING. As a means of carrying scent about the person, the FOUNTAIN FINGER-RING has recently become famous. The delight of all who have seen this little conceit is most gratifying to its inventor. It is at once useful and ornamental. By the least pressure, the wearer of the ring can cause a jet of perfume to arise from it at any time desired - thus every one can carry with him to a ball, concert, or sick chamber, enough scent, so refreshing! for the time being. The practical application of this invention causes a good deal of merriment and laughter. A gentleman who abhors perfume, unless it be snuff, 'squeezing' a lady's hand, will receive a shower of the eternal frangipanni or kiss-me-quick, much to the delight of all present at being thus sweetly 'found out.' The rings can be filled with perfume with the greatest ease - thus: Press the ball at the back of the ring nearly flat, pour scent into a cup and dip the ring into it; the elasticity of the ball will then draw the perfume into the interior till full." (The Lady's Newspaper, November 2, 1861; Piesse 1879, 4th ed.: 303).

28 Arthur St. John Adcock (1864-1930) was a Fleet Street journalist, editor and main writer of The Bookman (http://en.wikipedia.org/wiki/Arthur_St._John_Adcock). His editor, George Robert Sims (1847-1922) was also a London journalist (http://en.wikipedia.org/wiki/George_Robert_Sims). 
(15) There is no other fair like Whit Monday's on Wanstead Flats. Here is a square mile and more of open land where you may howl at large; here is no danger of losing yourself as in Epping Forest; the public-houses are always with you; shows, shies, swings, merry-go-rounds, fried fish stalls, donkeys are packed closer than on Hampstead Heath; the ladies' tormentors are larger, and their contents smell worse than at any other fair. Also, you may be drunk and disorderly without being locked up - for the stations won't hold everybody - and when all else has palled, you may set fire to the turf. Hereinto Billy and Lizerunt projected themselves from the doors of the Holly Tree on Whit Monday morning. But through hours on hours of fried fish and half-pints both were conscious of a deficiency. For the hat of Lizerunt was brown and old; plush it was not, and its feather was a mere foot long and of a very rusty black. Now, it is not decent for a factory girl from Limehouse to go bank-holidaying under any but a hat of plush, very high in the crown, of a wild blue or a wilder green, and carrying withal an ostrich feather, pink or scarlet or what not; a feather that springs from the fore-part, climbs the crown, and drops as far down the shoulders as may be. Lizerunt knew this, and, had she had no bloke, would have stayed at home. But a chance is a chance. As it was, only another such hapless girl could measure her bitter envy of the feathers about her, or would so joyfully have given an ear for the proper splendor. Billy, too, had a vague impression, muddled by but not drowned in halfpints, that some degree of plush was condign to the occasion and to his own expenditure. Still, there was no quarrel; and the pair walked and ran with arms about each other's necks; and Lizerunt thumped her bloke on the back at proper intervals; so that the affair went regularly on the whole: although, in view of Lizerunt's shortcomings, Billy did not insist on the customary exchange of hats.

Everything, I say, went well and well enough until Billy bought a ladies' tormentor and began to squirt it at Lizerunt. For then Lizerunt went scampering madly, with piercing shrieks, until her bloke was left some little way behind, and Sam Cardew, turning up at that moment and seeing her running alone in the crowd, threw his arms about her waist and swung her round him again and again, as he floundered gallantly this way and that, among the shies and the hokey-pokey barrows.

Morrison (1894: 23-24) Tales of Mean Streets. 
(16) Circus and menagerie, swing-boats, roundabouts, shooting-galleries - all were gone. The whole area lay trampled and bare, with puddles where the steam-engines had stood, and in the puddles bedabbled relics of paper brushes, confetti bags, scraps torn from feminine flounces, twisted leaden tubes of "ladies' tormentors" cast away and half-trodden into the mire; the whole an unscavenged desolation.

Quiller-Couch (1909: 21) True Tilda.

From pictorial art we learn of another custom: that of Bank Holiday tumbling. In Modern London; being the History of the Present State of the British Metropolis (Phillips: 1804), Richard Phillips commissioned artist Edward Pugh to provide drawings to be engraved as illustrations. Pugh's view entitled Greenwich Park with the Royal Observatory on Easter Monday was engraved by J. Pass, and shows a crowd of people, some of whom are tumbling down the hill (Phillips 1804: 477). Barrell (2012: 188) quotes the commentary: "The hill [...] is the principal attraction to the merry-making folks. It is extremely steep, and usually thronged; and, every now and then, a group of young men and women, locked hand in hand, rush down this path at full speed; the grand jest and enjoyment of the scene consisting in the falls that happen to the females as well as the males in this slippery enterprise." Barrell presents other views dated between 1740 and 1811 (2012: 188-91) which also depict holiday tumbling at Greenwich, showing that this custom had quite a long history. He has collected together references to Whit Monday tumbling in drama and verse (2012: 188, 190,192), and his article makes the point that Pugh's drawings show the middle and the lower classes enjoying their Bank Holiday outings together; that Bank Holiday behaviour (such as swapping hats, squirting ladies and tumbling down the hill) was enjoyed by the middling sort as well as the working classes. Returning to Piesse and Lubin's Box His Ears, Tom-Boy, Pop-Kiss, Laughing Water, Follow Me, Lads!, Kiss Me, and Let Me go, Kiss Me, You Dare!, and the Fountain Finger Ring: these names invoke the kind of flirtatious behaviour permitted to middle and working-class women on Bank Holidays. It was horse-play, a roughand-tumble, appealing to youth. There was a physicality about Bank-Holiday licence, where men squirted women and pulled them violently down a hill. Piesse and Lubin also named a perfume Leap Year Bouquet, advertised with the quotation "“In leap year they have power to choose; Ye men no charter to refuse." Chaucer”; and a perfume named St. Valentine's. ${ }^{29}$ Piesse and Lubin's humorous

29 The Times March 12, 1860 and February 11, 1896 (1860 and 1896 being leap-years); Morning Post, August 30, 1862. 
flirtatious perfume-titles had a purpose beyond the obvious appeal to holiday fun. Kiss-Me-Quick, Tom-Boy, Pop-Kiss, Box-His-Ears, Follow Me, Lads!, Kiss Me, You Dare, sold women the fantasy of taking the initiative in matters of romance, in a society which did not allow it, apart from on the three Bank Holiday outings of the year, Valentine's Day, and leap-years. Socially-elevated women were prevented by their social class from participating in Bank Holiday get-togethers, but all, apart from the poorest, could be reached by advertising.

\section{Conclusion}

This survey of traders' influence on English leads me to conclude that traders' contributions to the English language are as worthy of inclusion in historical dictionaries as hapax legomena from learned sources. Trading terminology is just as informative for understanding linguistic change as words from other domains. If firework names are omitted from a history of the development of the suffix -oon, for example, then the social dimension of the popularity of the suffix remains hidden - fireworks being essentially a matter of fashion. It is true that nobody nowadays refers to callawapores or kyanising, but they did once, and frequently and in great numbers, and such names carry information about society at the time. Commodity-names such as Suez Canal and Box-His-Ears reveal traders' expectations of prospective customers, so long as they are viewed from the wider social context (an inference that customers thought that the perfume actually smelled of the Suez Canal would in all likelihood be inaccurate). Before the nineteenth century, non-essential commodities were sold on an appeal to social betterment, but after that date, royalty shifted goods less than novelty. Novelty, as an inducement, started early: the appeal of morphemes - pore, seer- and -oon was not phonological or grammatical but social, -pore and seer- signalling 'brand-new, latest cloth imports', and -oon signalling, in context, 'latest type of firework'. The British Empire, in sum, was a global union of traders, whose seemingly endless conveyor-belt of latest terminology infiltrated everyone's usage of everyday English.

\section{References}

Adcock, A. St. John. 1903. Bank holiday London. In George R. Sims (ed.), Living London. vol 2, 114-120. Fuller: London.

Boosey's Christy's minstrels album containing their twelve most popular songs. 1856: New York: Firth, Pond \& Co. 
'Boz' (Dickens, Charles). 1837. Bentley’s Miscellany, 1: January.

Hitching, Claude \& Jenny Lilly. 2012. Rock landscapes: The Pulham legacy. Woodbridge: Garden Art Press.

Lee-Whitman, Leanna. 1982. The silk trade: Chinese silks and the British East India Company. Winterthur Portfolio 17(1) (Spring). 21-41.

Morrison, Arthur. 1894 [1912]. Tales of mean streets. London: Methuen \& Co. Ltd.

Lave, Jean \& Etienne Wenger. 1991. Situated learning: Legitimate peripheral participation. Cambridge, Cambridge University Press.

O’Brien, Patrick, Trevor Griffiths \& Philip Hunt. 1991. Political components of the industrial revolution: parliament and the English cotton textile industry, 1660-1774. Economic History Review, XLIV, 3. 395-423.

Oberthur, René, Dauthenay, Henri, Mouillefert, Julien, Harman Payne, C., Leichtlin, Max, Severi, N. \& Cortés, Miguel. 1905. Répertoire de Couleurs pour aider à la détermination des couleurs des Fleurs, des Feuillages et des Fruits. Société Française des Chrysanthémistes. Rennes: Imprimerie Oberthur and Paris: Librarie Horticole.

Piesse, G. W. Septimus. [1857] 1879. The art of perfumery, and the methods of obtaining the odours of plants. 4th edn. London: Longmans, Green, \& Co.

Quiller-Couch, A. T. 1909. True Tilda. Bristol \& London: J. W. Arrowsmith; Simkin, Marshall, Hamilton, Kent \& Co. Ltd.

Winsor \& Newton. 1878-1882. Specimen tints of Winsor \& Newton's artists' oil and water colours. London: Winsor \& Newton.

Wright, Laura. 2010. Eighteenth-Century London Non-Standard Spellings as Evidenced by Servants', Tradesmen's and Shopkeepers' Bills. In Nicholas Brownlees, Gabriella Del Lungo \& John Denton (eds.), The language of public and private communication in a historical perspective, 161-190. Cambridge: Cambridge Scholars Publishing.

Wright, Laura. 2011a. Semantic shift of the colour-terms maroon and magenta in British Standard English. Revista de Lengua para Fines Específicos 17. 341-376.

Wright, Laura. 2011b. The nomenclature of some French and Italian fireworks in eighteenth-century London. The London Journal 36(2). 109-39.

Wright, Laura. 2013. On Dickens and Kyanising, Joyce Grenfell and Vassarettes, Barbara Pym and Kestos - or, historical brand names: nouns, evidence and usage. Babel - The Language Magazine 2 (February). 16-21.

Wright, Laura. In press. On the East India Company vocabulary of the island of St Helena, South Atlantic, 1676-1720. World Englishes.

Yule, Henry \& Arthur C. Burnell. 1886 [1993]. Hobson-Jobson: A glossary of colloquial Anglo-Indian words and phrases, and of kindred terms, etymological, historical, geographical and discursive. London, reprinted Ware: Wordsworth.

\section{Online Resources}

British Library Newspapers 1600-1950 (Gale Cengage British Newspapers 1600-1950). http:// gale.cengage.co.uk/british-newspapers-16001950.aspx (03 March, 2015.)

Chronicling America: Historic American Newspapers. http://chroniclingamerica.loc.gov/

(03 March, 2015.)

Collins English Dictionary. http://www.collinsdictionary.com/ (03 March, 2015.) 
Early English Books Online (EEBO). http://eebo.chadwyck.com/home (03 March, 2015.)

Eighteenth Century Collections Online (ECCO). http://gale.cengage.co.uk/product-highlights/ history/eighteenth-century-collections-online.aspx (03 March, 2015.)

Google NGram Viewer. https://books.google.com/ngrams (03 March, 2015.)

Oxford English Dictionary Online. www.oed.com (03 March, 2015.)

Royal Mail database. http://www.royalmail.com/ (03 March, 2015.)

Times Digital Archive. http://archive.timesonline.co.uk/tol/archive/ (03 March, 2015.) 